Tamil Nadu

kamala.thiagarajan@gmail.com Cite this as: BMJ2020;370:m3506 http://dx.doi.org/10.1136/bmj.m3506 Published: 10 September 2020

\section{HEALTHCARE IN INDIA}

\section{Covid-19 exposes the high cost of India's reliance on private healthcare}

\author{
India's private sector props up its healthcare, but the pandemic has exposed exorbitant and \\ inconsistent billing. Kamala Thiagarajan reports on the patients and authorities picking up the tab
}

\section{Kamala Thiagarajan freelance journalist}

On 12 April, a businessman living in Kolkata accompanied his 57 year old mother to the government run hospital close to his home. She'd had a low grade fever for days and a history of chronic lung issues when she developed breathlessness. The hospital didn't have a ventilator and conditions there were very bad, he says, so he instead admitted her to a privately run corporate hospital.

The hospital staff put her on oxygen and administered a covid-19 test, which turned out positive. Meanwhile, the hospital began billing incessantly. "There were a lot of hidden costs that I could not understand," he says. "I wondered whether much of the medication or treatment was necessary, but whom could I check with? I didn't have the power or strength to even complain.”

On 9 May he lost his mother, but he was told that he had to settle a bill of 1.5 million rupees (£15 750; $€ 17$ 300; \$20 400), which he disputed. After much negotiation the hospital finally lowered the charges to one third of that amount, which he recently settled.

As the pandemic has spread, so have demands for the Indian government to regulate the rising costs of healthcare in private hospitals, which provide the bulk of the country's medical treatment. India has nearly twice as many private hospitals as public ones-an estimated 43487 versus $25778^{1}$-despite about $85.9 \%$ of India's rural population and $80.9 \%$ of its urban population having no health insurance. ${ }^{2}$

Treatment at public medical facilities is free, but the quality of care varies greatly among states, and covid-19 has exposed the lack of government investment in terms of equipment, facilities, and staff. “Existing vacancies haven't been fulfilled, even as government run hospitals struggle without adequate manpower," says Inayat Singh Kakar, a public health researcher with the People's Health Movement in New Delhi. ${ }^{3}$

Most ventilators are available only in private hospitals, and even then they're concentrated in just seven states. ${ }^{1}$ All of this serves to drive desperate patients towards private healthcare-if they can afford it.

\section{Measures and mixed results}

In April, Sachin Jain, a lawyer based in New Delhi, filed a public interest litigation-a legal case filed in the public interest-with India's Supreme Court, drawing attention to the high costs charged by private hospitals for covid-19 treatment. Although ongoing, the case has led many state governments to try out potential solutions, spurred on by pressure from the Central (federal) Government's health ministry and building on the existing efforts of some states to assert some control.

The northeastern state of West Bengal announced that treatment should be completely free at public and private hospitals handling covid-19 cases, but it was unable to get most large corporate private hospitals on board. In New Delhi private hospitals were asked to apply subsidised rates on as much as $60 \%$ of total hospital beds, but many patients complained of being directed to unsubsidised beds first. 4

City administrations in Bengaluru, Mumbai, and Hyderabad have successfully taken action against private hospitals, obtaining refunds for patients who had been overcharged for covid-19 treatments. The southern Indian state of Telangana has made itemised billing mandatory, to make it easier to identify overcharging.

And Maharashtra, one of the first states to be affected by covid-19, has doubled the number of private hospitals in its integrated state health insurance scheme to 1000 and extended it to families with an annual income of 100 ooo rupees or less. The state also implemented a rate cap on the cost of covid and non-covid treatments at private hospitals-a measure that's being tried throughout the country.

\section{Rate caps}

Prices for privatised healthcare should be easy enough to regulate for a federal government, says Murali Neelakantan, a lawyer specialising in healthcare. "It's not difficult to fix a price for all already done this for civil servants under the Central Government Health Scheme, enabling them to claim free treatment in government hospitals and discounts for specific treatments in 1200 privately run hospitals around the country.

“There's no reason why [procedures] are cheaper for government employees than they are for the common man," says Neelakantan. "The formula and the solution for price regulation exists, and it can be easily applied across India.”

So far, the central government hasn't tried anything so wide ranging. But state governments are experimenting with rate capping in the pandemic. In a series of tweets in June, the spokesperson for the Ministry of Home Affairs in Delhi said that a committee had recommended caps in 350 private hospitals," he says, noting that the government has 
Delhi hospitals: 10 ooo rupees a day for covid-19 patients who require beds and personal protective equipment (PPE); 15 ooo rupees for those needing to be admitted to intensive care; and 18 ooo rupees for those requiring ventilator support. ${ }^{5}$ More than 10 other states in India, including Punjab, Tamil Nadu, Andhra Pradesh, and Jharkhand, have brought in policies to subsidise covid-19 treatment in private hospitals.

Despite this, however, activists say that caps throughout the country are not being enforced. Many private hospitals simply choose not to comply, with no penalty, and different states follow different rules. Kakar says, "The price cap in Delhi included the cost of PPE, interventional procedures, high end medicines, and treatment of comorbidities during covid-19 treatment, but states like Maharashtra did not include this.”

The caps have also allowed some insurance companies to avoid paying for treatments. One patient from the south Indian city of Tiruchirappalli told The BMJ under anonymity that she and her elderly mother had been charged 320 ooo rupees for a room and treatment for 11 days, after testing positive for covid-19 in July. Their insurance company said that only 100 ooo rupees could be covered despite them paying for annual medical insurance cover of 5 million rupees. The company said that the remaining amount should not have been charged by the hospital in the first place, as per the government stipulations.

"They told me that I could fight with the hospital if I wanted to and refused to pay the balance amount," she says. She chose not to because she didn't want to be blacklisted by the only major private hospital chain in her town.

\section{Where there's a will...}

Parang Mehta, a paediatrician running his own practice in Surat, Gujarat, says that it's not right for the private sector to provide most of the country's healthcare needs. "Even businesses should have a moral compass and refrain from exploiting human desperation," he says. But private healthcare has long been a lucrative business in India, so question marks remain over the will of the sector to implement change.

"It is a kind of existential threat for corporate healthcare," says Malini Aisola, co-convenor of the All India Drug Action Network, a coalition campaigning for affordable healthcare. "We need regulatory reforms that carry forward into the long term-beyond the emergency that the pandemic has created. We need a more systematic approach to regulating the private sector."

Kakar adds, "[Private hospitals] are trying to subvert any kind of fallout of regulation, especially to make sure that it doesn't extend beyond the pandemic. They don't want the commercial healthcare business model to be affected."

Still, activists say that, if there can be anything good about the pandemic, it's that the exploitative billing practices of the private sector are finally coming under scrutiny.

Competing interests: I have read and understood BMJ policy on declaration of interests and have no relevant interests to declare.

Provenance and peer review: Commissioned, not peer reviewed.

1 Kapoor G, Sriram A, Joshi J, Nandi A, Laxminarayan R. Covid-19 in India: state-wise estimates of current hospital beds, intensive care unit (ICU) beds and ventilatorsCenter For Disease Dynamics, Economics \& Policy. 21 Apr 2020. https://bit.ly/3m3V4th.

2 Government of India. Key indicators of social consumption in India: health. Nov 2019. http://mospi.nic.in/sites/default/files/publication_reports/KI_Health_75th_Final.pdf.

3 Jan Swasthya Abhiyan. https://phmindia.org/about-us/.
4 Delhi govt to subsidise beds, procure oxygen tanks for covid-19 patients in private hospitals Wire2020 Jun 21. https://thewire.in/health/delhi-govt-to-subsidise-beds-procure-oxygen-tanksfor-covid-19-patients-in-private-hospitals.

5 Ministry of Home Affairs, Government of India. Twitter. 19 Jun 2020. https://twitter.com/PIBHomeAffairs/status/1273872167269068800?s=20.

This article is made freely available for use in accordance with BMJ's website terms and conditions for the duration of the covid-19 pandemic or until otherwise determined by BMJ. You may use, download and print the article for any lawful, non-commercial purpose (including text and data mining) provided that all copyright notices and trade marks are retained. 